\title{
EFFECTS OF IMPREGNATION WITH STYRENE AND NANO-ZINC OXIDE ON FIRE-RETARDING, PHYSICAL, AND MECHANICAL PROPERTIES OF POPLAR WOOD
}

Keywords:

Fire retarding properties

Nanocomposite

Nano-zinc oxide

Wood polymer composites

Histórico:

Recebido 12/08/2016

Aceito $16 / 11 / 2016$

Palavras chave:

Propriedades retardantes de fogo

Nanocompósitos

Óxido de zinco nano

Compósitos de polímero-madeira

${ }^{+}$Correspondência: htaghiyari@srttu.edu

$\mathrm{DOI}$
ABSTRACT: Nanoparticles have been vastly applied in wood polymer composites (WPCs) in the recent years to improve some of the drawbacks of solid wood species. In the present study, the effects of $\mathrm{ZnO}$ nanoparticles on fire retarding, physical, and mechanical properties of polymerized poplar wood were investigated. Poplar specimens were impregnated with styrene monomer, containing four different contents of nanozinc oxide $(\mathrm{ZnO})(0,0.5, \mathrm{I}$ and $\mathrm{I} .5 \%$, based on the dry weight of monomer). Results of the scanning electron microscopy (SEM) showed homogeneous dispersion of $\mathrm{ZnO}$ nanoparticles in the WPC matrix. Nano-zinc oxide improved physical properties such as dimensional stability and water absorption. Moreover, mechanical properties increased in comparison to the control specimens. The impregnation process also significantly improved some of the fire-retarding properties, including the ignition time; however, the flammability nature of styrene aggravated some others, such as carbonized area. It was concluded that, although most of the properties were improved, the final application of WPC should be taken in to consideration before making decision on whether or not to impregnate populus wood with styrene.

\section{EFEITOS DA IMPREGNAÇÃO COM ÓXIDO DE ESTIRENO E NANO-ZINCO SOBRE PROPRIEDADES RETARDADORAS DE FOGO, FÍSICAS E MECÂNICAS DA MADEIRA DE POPULUS}

RESUMO: Nanopartículas são amplamente aplicadas em compósitos de polímeromadeira (WPCs) nos últimos anos para melhorar algumas das desvantagens das espécies de madeira sólidas. No presente estudo, os efeitos de nanopartículas de $\mathrm{ZnO}$ nas propriedades de retardamento do fogo, propriedades físicas e mecânicas da madeira polimerizada de Populus foram investigadas. Espécimes de Poplar foram impregnados com monômero de estireno, contendo quatro diferentes conteúdos de óxido de nanozinco $(\mathrm{ZnO})(0,0,5$, I e I,5\%, com base no peso seco do monômero). A microscopia eletrônica de varredura (SEM) revelou homogênea dispersão das nanopartículas de ZnO na matriz WPC. O ZnO melhorou propriedades físicas da madeira tais como a absorção de água e estabilidade dimensional. Além disso, as propriedades mecânicas aumentaram em comparação com as amostras de controle. $O$ processo de impregnação também significativamente melhorou algumas das propriedades retardadoras de fogo, incluindo 0 tempo de ignição; no entanto, a natureza de inflamabilidade do estireno agravada alguns outros, como a área carbonizada. Concluiu-se que embora a maioria das propriedades foram melhoradas, a aplicação final do WPC deve ser tomada em consideração antes de tomar a decisão sobre a impregnar a madeira de Populus com estireno ou não.

Gorgan University of Agricultural Sciences \& Natural Reasources - Gorgan, Iran

${ }^{2}$ Shahid Rajaee Teacher Training University - Tehran, Iran

${ }^{3}$ Shahid Beheshti University - Mazandaran, Iran 


\section{INTRODUCTION}

With the development of human society, tree plantations and the consumption of wood are rapidly increasing year by year; moreover, a multipurpose attitude towards plantation of trees is growing worldwide (AMUSANT et al. 2015). However, wood and wood composites are susceptible to some organisms such as fungi and termites, as well as to fire (HILL, 2008; OZDEMIR \& TUTUS, 20I3\&2016). These vulnerabilities limit the applications of wood and wood composites. Researchers have therefore worked on engineered wood to improve the drawbacks, using new production techniques and modern materials at micro or nano scales (ANDRADE et al. 2016; BAL 2016; WANG et al. 2016).

Nano materials have been the subject of intense scientific and technological activities due to their interesting size dependent physicochemical and bio and green properties and consequently have exciting application potential (LI 20 I 2; GHARIEB et al. 2016). The first practical application of nanotechnology in wood science and technology was the use of metal nanoparticles with high thermal conductivity (SABER et al., 20I3) that increased the rate of heat transfer in solid wood (TAGHIYARI, 20I2\&20I4), increased resistance to decay (HABIBZADE et al., 20I4; FARAHANI and BANIKARIM, 20I3), and decreased the hot press time in particleboard manufacture. There was an improvement in physical and mechanical properties and fungal and fire retardancy by infusing wood with some mineral nanomaterials (KARIMI et al., 2013; TAGHIYARI et al., 20I3; RANGAVAR et al., 2016).

$\mathrm{Nano}-\mathrm{ZnO}$, as one of the multifunctional inorganic nanoparticles, has achieved and increasing attention in recent years due to its many significant physical and chemical properties, such as chemical stability, high light transmittance, effective antibacterial properties, and intensive ultraviolet and infrared adsorption (TURTON et al., 2004; HAMMINGA et al., 2004; WU et al., 2002; WU and XIE, 2004; KITANO and SHIOJIRI, I997; KAMAT et al., 2002). Moreover, the advance of nano$\mathrm{ZnO}$ particles could improve the mechanical and optical properties of the polymer matrix (RASHMI et al., 20I2).

There are studies reporting the use of nano-zinc oxide to improve physical and mechanical properties (RASHMI et al., 20I2), to act as a fire retardant (RASHMI et al., 20I3), and also as a wood preservative (HABIBZADE et al., 20I4, FARAHANI \& BANIKARIM, 20I3).

It should be added that the $\mathrm{ZnO}$ nanoparticles, like other nanoparticles, possess a high surface energy, which may result in the agglomeration of particles when $\mathrm{ZnO}$ nanoparticles are dispersed in an organic solvent and matrices. Therefore, it is necessary to prepare $\mathrm{ZnO} /$ polymer nanocomposites to prevent the formation of agglomerated nanoparticles. Surface modification is a common strategy to prevent the agglomeration of nanoparticles in polymers. On the other hand, grafting polymers on the surface of the nanoparticles effectively improves their dispersibility in the polymer matrix, resulting in enhanced properties of the composites. The surface modification of $\mathrm{ZnO}$ nanoparticles is achieved by grafting with silane coupling agent or with some polymers (SHU-RUI et al., 2008; TANG et al., 2006).

Poplar wood (Populus deltoids), a fast growing species with low-quality, is not useful for constructional purposes due to its poor dimensional stability, vulnerability to wood-deteriorating fungi, and low mechanical properties. The present study focused on the preparation of wood polymer nanocomposite by impregnating poplar specimens with styrene monomer, vinyl trichlorosilane (VTCS) and modified $\mathrm{ZnO}$ nanoparticles. The aim of the study was to find the effects of nano- $\mathrm{ZnO}$ on fire retarding, physical and mechanical properties of wood.

\section{EXPERIMENTAL}

\section{Materials}

Poplar wood (Populous deltoids L.) was collected from the Gorgan province, located in the Northern part of Iran. The chemicals for the production of WPCs were styrene (St) and glycidyl methacrylate (GMA), purchased from Merck \& Co., Inc. (Germany). ZnO nanopowder $\left(<50 \mathrm{~nm}, 90 \mathrm{~m}^{2} \cdot \mathrm{g}^{-1}\right)$ was purchased from Nano Pars Lima Co. (Tehran, Iran). Tetrahydrofuran (THF, anhydrous) and vinyl trichloro silane (VTCS) were purchased from Sigma-Aldrich chemical company (Darmstadt, Germany). All other chemicals and solvents used in this study were of analytical grade.

\section{Sample preparation}

Wood samples used for testing were prepared from clear and defect-free poplar wood, cut into blocks for different experiments. The dimensions of blocks were $2 \times 2 \times 2 \mathrm{~cm}^{2}$ for dimensional stability test (ASTM D4442), $I \times I \times 10 \mathrm{~cm}^{2}$ (radial $\times$ tangential $\times$ longitudinal) for flexural strength (ASTM D790), $10 \times 0.5 \times 2 \mathrm{~cm}^{2}$ for tensile strength (ASTM D638), and $2 \times 2 \times 6 \mathrm{~cm}^{2}$ for compression strength (ISO 3787). Seven replicate specimens were prepared for each treatment.

\section{Surface modification of nano-zinc oxide}

$\mathrm{ZnO}$ nanoparticles were treated with silane coupling agent. The surface modification of nanoparticles 
was carried out as follows: firstly, a $\mathrm{I} .0 \mathrm{~g}$ portion of $\mathrm{ZnO}$ nanoparticle, $1.0 \mathrm{~mL}$ of VTCS, and $40 \mathrm{~mL}$ of toluene were added into a three-necked round-bottom flask $(250 \mathrm{~mL})$ and refluxed at $80^{\circ} \mathrm{C}$ for $6 \mathrm{~h}$ under mechanical stirring. Then, the precipitate was centrifuged and extracted with ethanol for $12 \mathrm{~h}$ to remove the residual silane. At the last stage, the precipitate was dried in vacuum for $48 \mathrm{~h}$, and the double bonds were introduced onto the surface of the $\mathrm{ZnO}$ nanoparticle (Hong et al., 2009).

\section{Preparation of St/ZnO nanocomposite}

Glycidyl methacrylate (GMA) was mixed with styrene (St), as a cross-linker. Then, the different amounts of modified $\mathrm{ZnO}$ nanoparticles (0/5, I and I/5 wt\% of $\mathrm{St}$ ) were dispersed in St monomer in the presence of minimum amount of solvent (THF) and the dispersion was treated by ultrasonic instrument for $30 \mathrm{~min}$ at room temperature.

\section{Impregnation and polymerization procedure}

All the samples were oven dried at $100^{\circ} \mathrm{C}$ to constant weight before treatment and weights were measured. The samples were then impregnated by $\mathrm{St}$ monomer and $\mathrm{ZnO}$ nanoparticles for half an hour, using Bethel method. Once impregnated, the samples were kept in a chamber at room temperature for $30 \mathrm{~min}$ so that the excess chemicals would be drawn out of the samples. Each sample was then wrapped in aluminum foil to be cured in an oven for $24 \mathrm{~h}$ at $90^{\circ} \mathrm{C}$. The cured samples were then soxhlet extracted using chloroform to remove homopolymers, if any, formed during polymerization. Finally the samples were dried and weights were measured.

\section{MEASUREMENTS}

\section{Weight percent gain}

The weight percent gain (WPG) after polymer loading was calculated according to Equation I, where $W_{1}\left(\mathrm{~g} \mathrm{~cm}^{-3}\right)$ is oven-dry weight of wood blocks before polymer treatment, and $W_{2}\left(g \cdot \mathrm{cm}^{-3}\right)$ is oven-dry weight of block after polymer treatment.

WPG $(\%)=\left(W_{2}-W_{1}\right) \cdot\left(W_{1} \times 100\right)^{-1}$

\section{Volume increase (\%) after impregnation}

Percentage of volume increase after curing of wood samples was calculated using Equation 2, where $\mathrm{V}_{0}$ is the oven-dry volume of the control wood and $V_{t}$ is the oven-dry volume of the impregnated wood.
Volume increase $(\%)=\left(V_{t}-V_{0}\right) \cdot\left(V_{0} \times 100\right)^{-1}$

\section{Water uptake test}

Both control and impregnated wood samples were immersed in distilled water at $20^{\circ} \mathrm{C}$ and weight was taken after different time intervals. It is expressed as, where $W_{t}$ is the weight after immersion in distilled water for specific time period (0-160 hours) and $W_{d}$ is the weight of the oven-dry sample.

Water uptake $(\%)=\left(W_{t}-W_{d}\right) \cdot\left(W_{d} \times 100\right)^{-1}$

\section{Mechanical properties}

A Universal Instron testing machine with a load capacity of $2000 \mathrm{kgf}$ was used to carry out the mechanical tests. Samples were stored at $20 \pm 1{ }^{\circ} \mathrm{C}$ and relative humidity of $65 \pm 5 \%$ inside a climatic chamber for two weeks before the tests.

\section{Fire-retardant testing apparatus}

Due to the unavailability of the standard tests by cone calorimeter and heat release measurement apparatus, Slide Fire Test Apparatus (SFTA) was designed and built (TAGHIYARI, 20I2), using piloted ignition (WHITE \& DIETENBERGER, 1999) (Figure I). The fuel in the present study was natural gas comprised mainly of methane $\mathrm{CH}_{4}$ (90-98\%); however, other hydrocarbons were also reported by the supplier to be accompanied $\left(\mathrm{C}_{2} \mathrm{H}_{6}\right.$ : I 8\%; $\mathrm{C}_{3} \mathrm{H}_{8}: 2 \% ; \mathrm{H}_{4} \mathrm{H}_{10}+\mathrm{C}_{5} \mathrm{H}_{12}$ : less than I\%; and also $\mathrm{N}_{2}+\mathrm{H}_{2} \mathrm{~S}+\mathrm{H}_{2} \mathrm{O}$ : less than $\left.1.5 \%\right)$. The flow rate was $0.096 \mathrm{~L} \cdot \mathrm{s}^{-1}$. The specimen was vertically mounted on a holder up-straight and exposed to a Bunsen type burner held at 45 degrees to the surface of the specimen for 120 seconds in accordance with the standard ISO I|925-3. The burner nozzle internal diameter was II $\mathrm{mm}$. The burner was fixed on a slide, moving back and forth, equipped with an adjustable stop to keep flame at a certain distance from the specimen. While the slide was back, the burner was turned on; the slide was then pulled forward abruptly to expose the flame to the specimen. The time for each specimen to catch fire with an evident visible flame on the spot nearest to the Bunsen-type burner, as well as the time the spot started to glow, were registered as ignition and glowing times. After 120 seconds, the slide was pulled back to prevent over exposure of the specimen to the flame. The time the specimen showed a visible fire, after the removal of the burner, was also registered as fire endurance time (the duration time of a visible flame). 

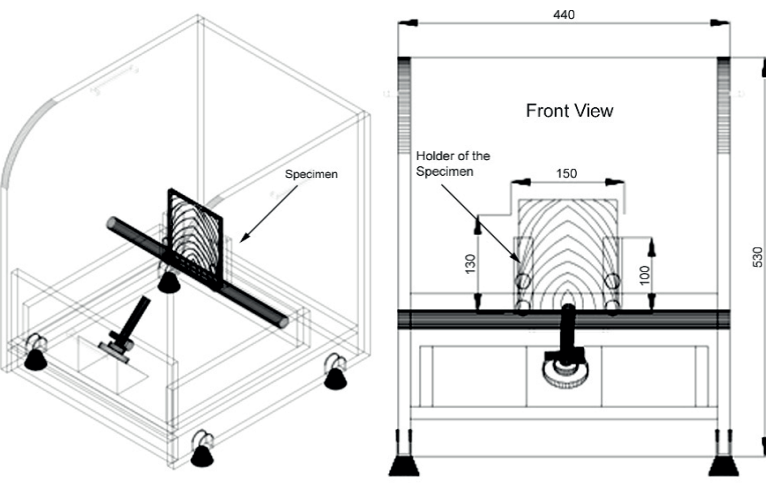

FIGURE I Schematic picture of the slide fire testing apparatus (SFTA) (invented by the second author under Iranian Patent No. 67232; approved by Iranian Research Organization for Science and Technology under license No. 3407 issued to H.R. Taghiyari) (TAGHIYARI, 20I2).

Once the flame was extinguished and the specimen was no longer burning, the length and width of burning were measured. The weight was also measured just before, as well as $2 \mathrm{~h}$ after the test, to measure the weight loss. The whole structure of the apparatus was placed in a three-wall-compartment in order to protect the burning flame from wind and air movements.

\section{Statistical analysis}

SPSS (16) was used for statistical analysis and significance was determined at I and $5 \%$ level of confidence using analysis of variance (ANOVA). Treatments were then classified as per Duncan's multiple range test.

\section{Weight percent gain (WPG \%)}

The values of WPG for both raw wood and WPCs for samples test were measured (Table I).

TABLE I Average weight gain of speciment after polymerization for fire-retarding, physical, and mechanical properties.

\begin{tabular}{ccc}
\hline Sample particulars & $\begin{array}{c}\text { Weight gain } \\
(\%)\end{array}$ & $\begin{array}{c}\text { Volume } \\
\text { increase }(\%)\end{array}$ \\
\hline Impregnated with ST/THF/BP/GMA/ZnO & & \\
100/20/2/I/0 & $50( \pm 5.6)^{*}$ & $3.28( \pm 3.8)$ \\
$100 / 20 / 2 / 1 / 0.5$ & $50( \pm 4.1)$ & $3.64( \pm 0.9)$ \\
$100 / 20 / 2 / 1 / 1$ & $50( \pm 6.8)$ & $3.17( \pm 2.6)$ \\
$100 / 20 / 2 / 1 / 1.5$ & $50( \pm 2)$ & $3.84( \pm 2.8)$ \\
\hline
\end{tabular}

* Numbers in the parenthesis are the standard division.

\section{RESULTS AND DISCUSSION}

\section{Analysis of the scanning electronic microscope}

\section{SEM results}

Figure 2 shows the SEM micrographs of the control (Figure 2a) and impregnated poplar wood specimens (Figure 2b-d). The empty cell wall and pits were clearly observed in the control wood (Figure 2a). In the impregnated specimens (Figure 2b), the empty spaces and part of the cell cavities were filled with Stpolymer. The impregnated nanoparticles as white spots were uniformly scattered in the composite (Figure 2c-d). No agglomeration of nanoparticles was observed.
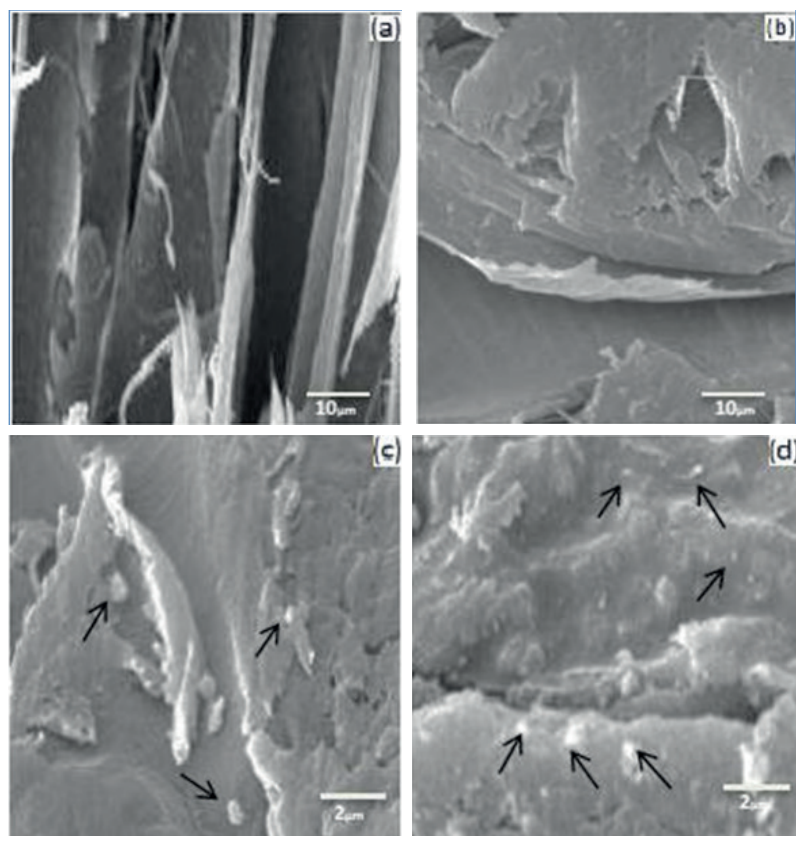

FIGURE 2 SEM images of wood (a) control and impregnated with (b) St, (c) $\mathrm{St} / \mathrm{ZnO}$ (0.5\%), and (d) $\mathrm{St} / \mathrm{ZnO}$ ( $1.5 \%$.).

\section{Water uptake}

Results of the water uptake tests showed that impregnation with styrene significantly decreased water uptake in comparison to the control samples (Figure 3). In both impregnated and control samples, water uptake increased with increasing time of immersion. The hydrophilic nature of wood (high contents of hydroxyl groups in cellulose and hemicelluloses) was responsible for the increasing trend. Additionally, large number of porous tubular structures in the control wood accelerated the penetration of wood due to the capillary action. The decreased water uptake was due to the hydrophobic characteristic of monomers, acting as a physical shield for the wood surface, keeping cell wall and lumen from getting wet by water penetration. The average water absorption percentage decreased with increasing nano-zinc oxide. In addition, the lowest water uptake of WPCs showed in high concentration samples of nano-zinc oxide. The tortuous path provided by the nano-zinc oxide layers increased the barrier property for water transport (CLAUSEN et al., 2010; RASHMI et al., 20I2). 


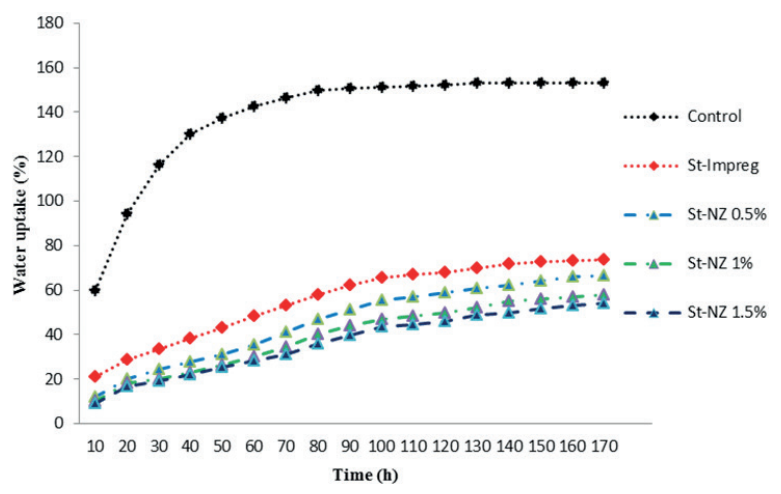

FIGURE 3 Effect of nano-ZnO content on water absorption (\%) in the control, impregnated with styrene (St-Impreg), impregnated with styrene containing $0.5 \%$ (St-NZ $0.5 \%)$, I\% (St-NZ I\%), and I.5\% nano-ZnO (St-NZ I.5\%) poplar specimens.

\section{Dimensional stability test}

The results of volumetric swelling in water for control and impregnated wood samples at room temperature for different time periods are shown in Figure 4. The reduction in volumetric swelling with increasing nano-zinc oxide suggested that higher concentrations of $\mathrm{ZnO}$ provided substantial water resistance (SOLTANI et al., 2013). The improvement in dimensional stability samples containing $\mathrm{ZnO}$ can be attributed to the void being occupied by $\mathrm{ZnO}$ nanoparticles (RASHMI et al., 2012).

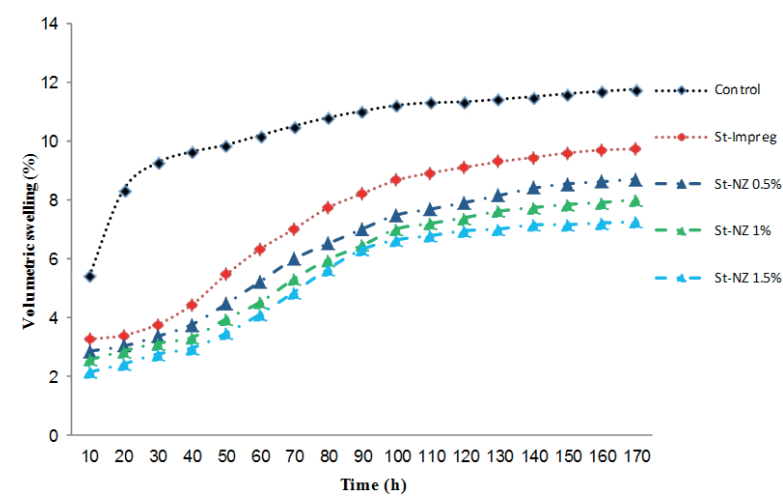

FIGURE 4 Effect of nano-ZnO content on dimensional stability (\%) of the control (W), impregnated with St (WPCN $0)$, poplar impregnated with styrene containing $0.5 \%$ nano-ZnO (WPCN 0/5), ST/ $1 \%$ nano-ZnO (WPCNI), ST/I.5\% nano-ZnO (WPCN I/5).

\section{Mechanical properties}

\section{Tensile strength and modulus}

Figure s 5 (a) and (b) illustrate the tensile strength and modulus of WPCs made with different nano-zinc oxide contents. It can be seen that with the increase in the nano-zinc oxide loading from 0 to $1.5 \mathrm{wt} \%$, there was improvement in the tensile strength and modulus of nanocomposite. The maximum improvement in tensile strength (26\%) and modulus (26.1\%) was achieved when $1.5 \mathrm{wt} \%$ of $\mathrm{ZnO}$ was added into the styrene matrix. The increased tensile strength up to $1.5 \mathrm{wt} \% \mathrm{ZnO}$ may be attributed to the higher extent of interaction of $\mathrm{ZnO}$ with wood and styrene through its surface hydroxyl and vinyl groups of polymer chains (RASHMI et al. 20I2, 2013; GUO et al. 2006, 2008). Nevertheless, with further increase in nano-zinc oxide loading from I to $1.5 \mathrm{wt} \%$, a low increase in the tensile strength and tensile modulus was observed. This indicated the nano-zinc oxide was distributed more uniformly through the polymer matrix at its lower concentrations (I wt\%); this uniform distribution, in turn, improved a better surface contact between nano-zinc oxide and polymer matrix. However, it should be noticed that more concentrations of $\mathrm{ZnO}$ ( $1.5 \mathrm{wt} \%)$ caused decreased tensile properties of nanocomposite.

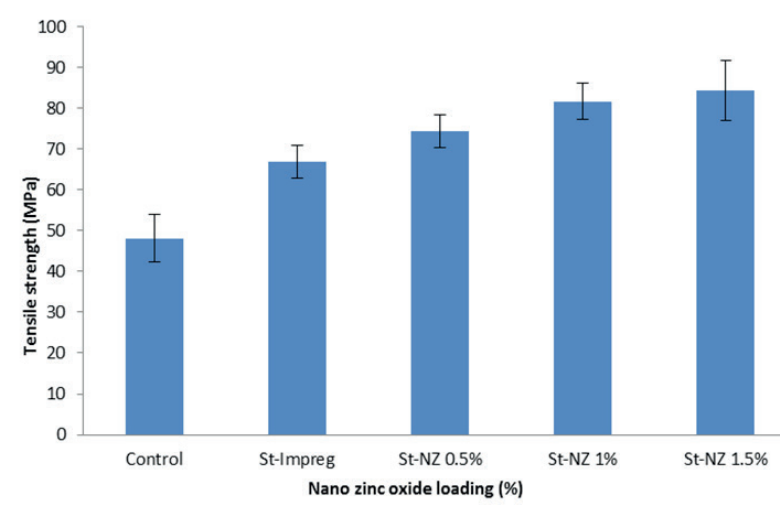

(a)

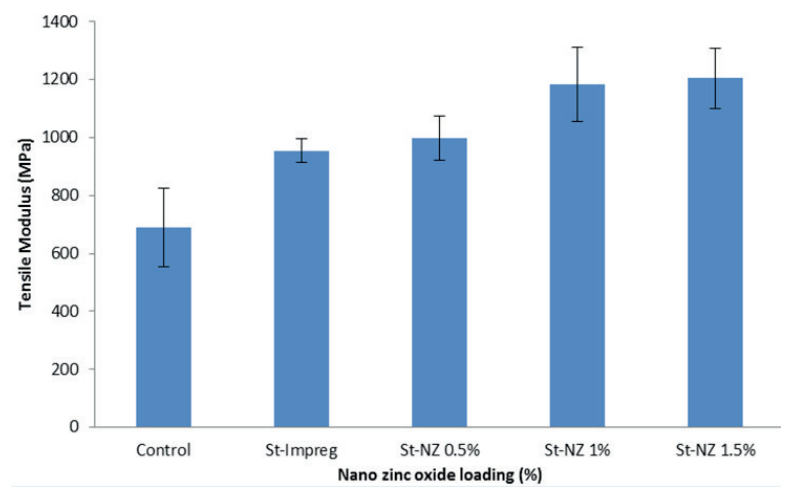

(b)

FIGURE 5 Effects of nano- $\mathrm{ZnO}$ content on: a) tensile strength; b) tensile modulus

\section{Flexural strength and modulus}

Results of flexural strength and flexural modulus are shown in Figure 6 ( $a$ and b), respectively. MOR and $M O E$ values increased with the increasing $\mathrm{ZnO}$ content. The maximum improvement in MOR $(24.8 \%)$ and MOE (20.4\%) was achieved when $\mathrm{I} .5 \mathrm{wt} \%$ of $\mathrm{ZnO}$ was added in the styrene matrix. The increase in properties was 


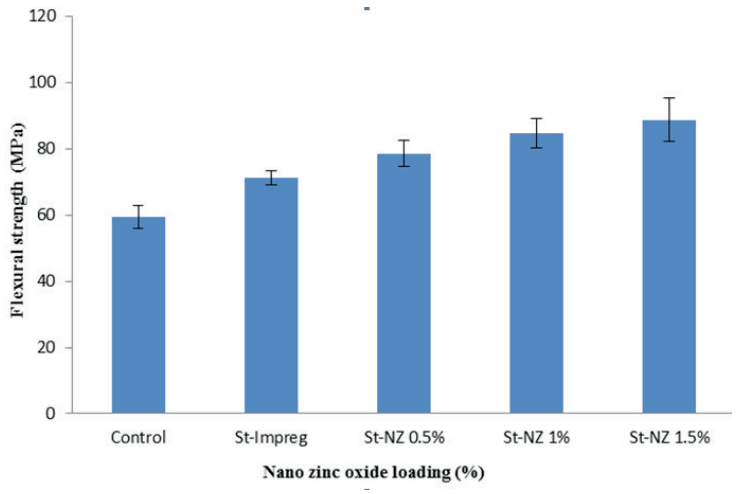

(a)

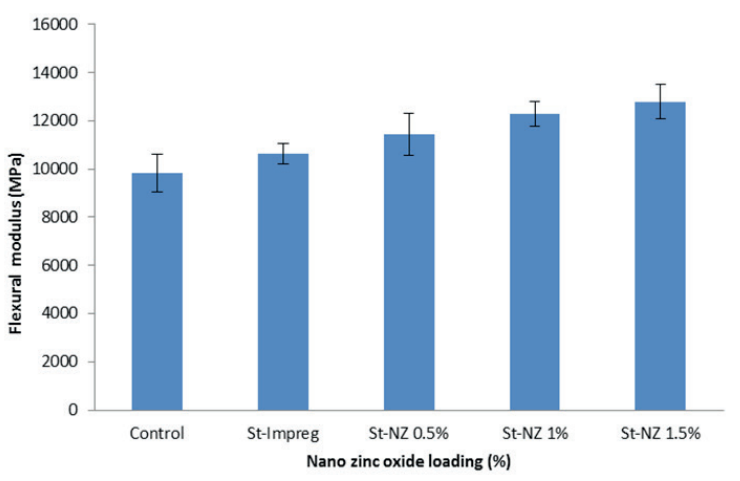

(b)

FIGURE 6 Effects of nano-ZnO content on: a) flexural strength; b)flexural modulus

attributed to the increasing positive interaction between wood, styrene and $\mathrm{ZnO}$ (RASHMI et al., 20I2), as well as good interfacial adhesion between the nano particles and the polymer chain.

\section{Compression strength}

A noticeable increase in compression strength was observed in the WPCs with nano-zinc oxide content (Figure 7). The highest strength was obtained in samples containing the highest $\mathrm{ZnO}$ content. The maximum improvement in compression strength (47.1\%) was achieved when 1.5

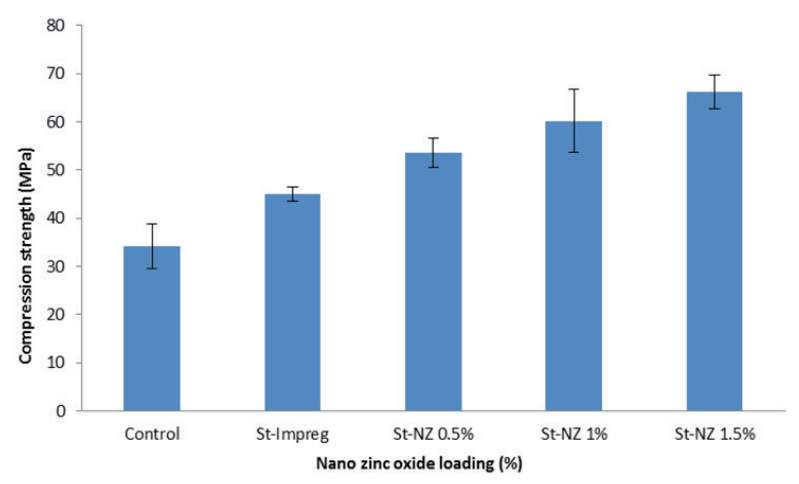

FIGURE 7 Effects of nano-ZnO content on compression strength $\mathrm{wt} \%$ of $\mathrm{ZnO}$ was added in the styrene matrix. This was attributed to the increasing positive interaction between wood, styrene and nano-zinc oxide. In addition, this interaction might have stiffened the composite due to reduction in mobility of the intercalated polymer chains, resulting in the enhancement of the compression strength.

\section{Fire retarding properties}

\section{Ignition Time}

$\mathrm{ZnO}$-containing WPCs demonstrated an improvement in the ignition time (Figure 8). The highest and lowest flammability times were observed in specimens containing $1.5 \%$ nano-zinc oxide $(20 \mathrm{~s})$ and the control ones (I5.4 s), respectively.

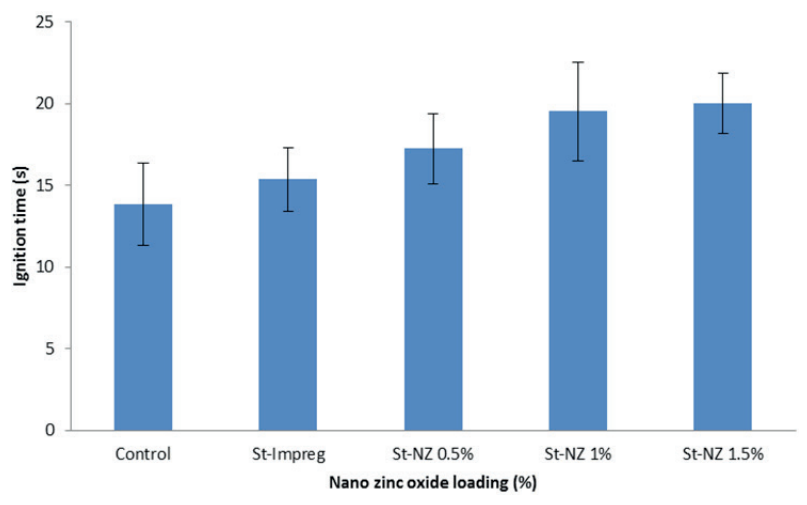

FIGURE 8 Effect of nano-zinc oxide content on ignition time.

\section{Glowing time}

Figure 9 shows the results of glowing time for all of treatments. Although nano-zinc oxide impregnated specimens indicated a slight increase in glowing time in the WPCs, the amount of increase was not significant in WPCs.

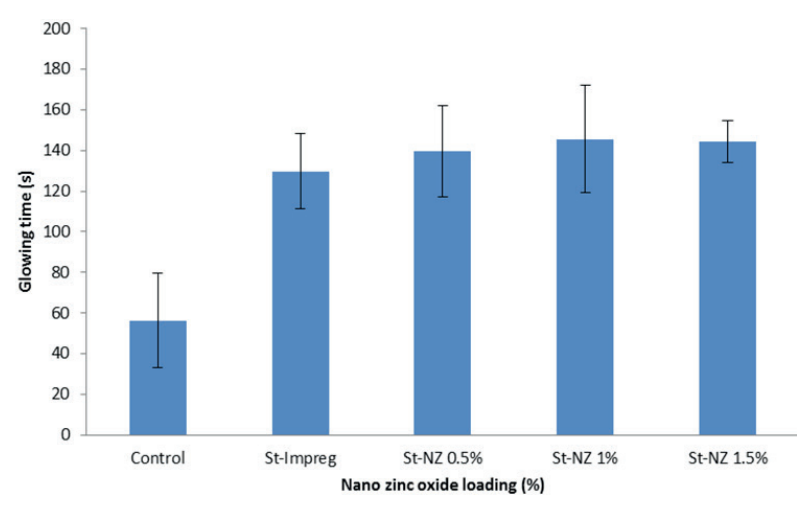

FIGURE 9 Effect of nano-znO content on glowing time.

\section{Carbonized area}

Nano-zinc oxide impregnation in all three concentrations resulted in a significant increase in the carbonized area (Figure 10). However, different 


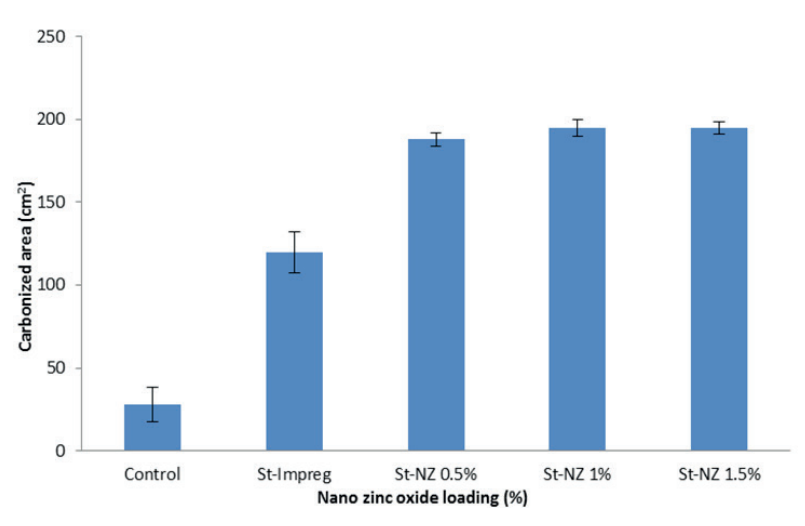

FIGURE I 0 Effect of nano-zinc oxide content on carbonized area.

concentration levels showed no significant difference in the carbonized area.

The increase in the ignition time was attributed to the heat-transferring property of metal nanoparticles (WANG et al., 20I0; LI, 20I2; TAGHIYARI, 20I2 \& 20I4). In fact, the heat was more quickly transferred from the spot nearest to the burning flame of the Bunsen-type burner, preventing the accumulation of heat to initiate the ignition on the spot (TAGHIYARI, 20I2). However, the flammability nature of styrene caused significant easier burning effect on the surrounding area of the spot, resulting in a significant increase in the carbonized area (Figure 10).

Cluster analysis based on all physical, mechanical, and fire-retarding properties showed clear remote clustering of the control specimens (Figure II A). The other four treatments containing styrene and zinc oxide were clustered rather based on their nano-zinc oxide content; that is, those treatments having no or little NZ ( 0 or $0.5 \%$ ) were clustered similarly, and those with higher NZ content (I and I.5\%) were closely clustered together. This indicated the significant effects of both impregnation with styrene and NZ content on the overall properties of WPC.

However, cluster analysis based only on physical properties showed that although the control specimens were clustered significantly different, the other four treatments were similarly clustered, showing no significant difference between them (Figure IIB). This demonstrated that impregnation with styrene had very significant effect on physical properties but $\mathrm{ZnO}$ content had no significant effect on water uptake and dimensional stability. Cluster analysis based only on mechanical properties demonstrated that the control specimens were clustered differently from the other four treatments (Figure IIC); however, the control was more closely clustered to the treatments with no or lower $\mathrm{ZnO}$ contents (St and St-NZ0.5\% treatments). This indicated that both $\mathrm{St}$ and $\mathrm{ZnO}$ nanoparticles had significant effect on mechanical properties. Cluster analysis based only on the fire properties showed that the control specimens were clustered significantly different (Figure IID). This showed that the flammability effect of styrene on ignition time and carbonized area (Figure s 8 and 10 ) resulted in the final clear different clustering of St-impregnated specimens. However, the cluster analysis also showed that those specimens impregnated with only styrene (with $\mathrm{ZnO}$ content of zero) showed a difference, although not very significant, with those St-impregnated specimens with $\mathrm{ZnO}$ content (Figure IID). This indicated that $\mathrm{ZnO}$ nanoparticles could prevent some of the negative effects on fire properties caused by the flammability of styrene.

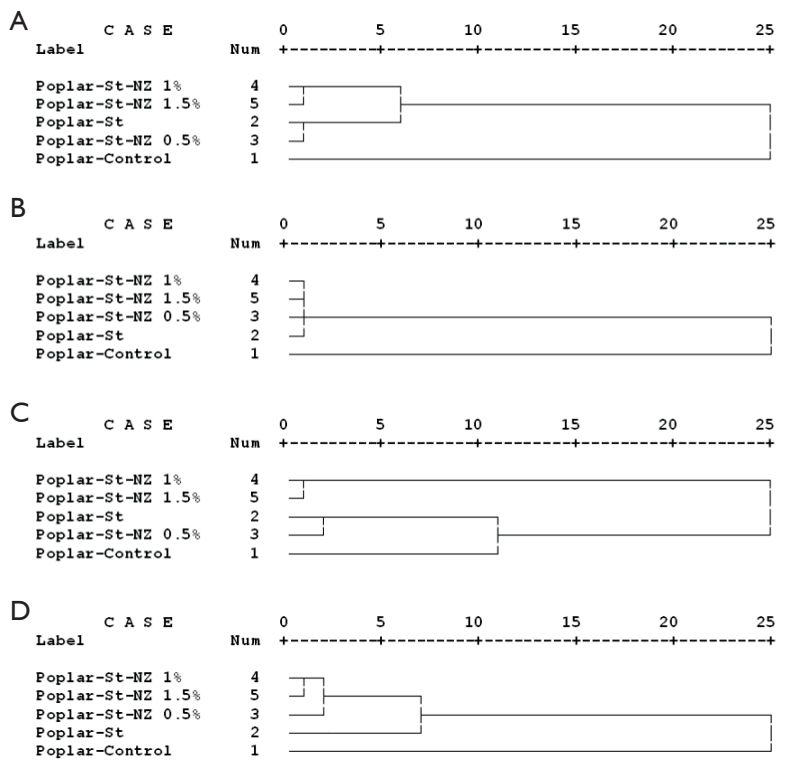

FIGURE I I Cluster analysis of the five treatments based on all physical, mechanical, and fire-retarding properties (A); based only on physical properties (B); based on mechanical properties (C); and based only on fireretarding properties $(\mathrm{D})(\mathrm{St}=$ styrene; $\mathrm{NZ}=$ nanozincoxide content).

It was therefore concluded that impregnation with styrene and $\mathrm{ZnO}$ depends entirely on the final application of the impregnated poplar wood; if the physical properties are of preliminary importance, St-impregnation can be recommended. If the mechanical properties are to be significantly improved, then both impregnation with St and NZ would be a better option. As to the fire properties, ignition time can be improved by impregnation with $\mathrm{ZnO}+\mathrm{ST}$; however, careful attention should be made because other fire properties could be aggravated.

\section{CONCLUSIONS}

Following conclusions were made based on the results of the present research project: 
I - Presence of zinc oxide nanoparticles significantly improves the physical and mechanical properties in poplar wood impregnated with styrene.

2- Nano-zinc oxide effectively improves some fire-retarding properties in the modified poplar wood. However, it should be noticed that the flammability nature of styrene does not allow all fire-retarding properties to be improved. The final application of WPC should therefore be carefully supervised.

\section{REFERENCES}

AMUSANT, N.; DIGEON, A.; DESCROIX, L.; BRUNEAU, O.; BEZARD, V.; BEAUCHENE, J. () Planting rosewood for sustainable essential oil production: Influence of surrounding forest and seed provenance on tree growth and essential oil yields. Bois et Forest Des Tropiques, v. 326, n. 4 , p. $57-65,2015$.

ANDRADE, A. C. D. A.; SILVA, J. R. M.; BRAGA JUNIOR, R. A.; MOULIN J. C. Distinction of mechanically processed wood surfaces with similar qualities using sunset laser technique. CERNE, v. 22, n. 2, p.159-162, 2016.

BAL, B. C. Some technological properties of laminated veneer lumber produced with fast-growing Poplar and Eucalyptus. Maderas Ciencia y tecnologia v. 18, n. 3, p. 4I3-424, 2016.

CLAUSEN, C. A.; GREEN, F;; AND KARTAL, S. N. Weatherability and Leach Resistance of Wood Impregnated with Nano-Zinc Oxide. Nanoscale Research Letters, v. 5, p.|464-|467, 2010.

FARAHANI, M.R.M. AND BANIKARIM, F. Effect of nano zinc oxide on decay resistance of wood plastic composites. BioResources, v. 8, n. 4, p. 57I5-5720, 2013.

GHARIEB, M.M.; MAGDY, Z. M.; EL SHOBAKY, A.; TAUFIK, W. HAFFEZ, E. E. The Green Synthesized Nanosilver and Their Effects on the Multidrug Resistant Bacteria Ribosomal DNA. Journal of Nanomaterials \& Molecular Nanotechnology, v. 5, n.4, 2016

GUO, Z.; LEI, K., LI, Y., NG, H. W.; PRIKHODKO, S.; AND HAHN, H. T. Fabrication and characterization of iron oxide nanoparticles reinforced vinyl-ester resin nanocomposite. Composite Science and Technology, v. $68,1513-1520,2008$.

GUO, Z.; PEREIRA, T.; CHOI, O.; WANG, Y.; AND HAHN, $H$. T. Surface functionalized alumina nanoparticle filled polymeric nanocomposites with enhanced mechanical properties. Journal of Materials Chemistry, v. 16, 28002808, 2006.

HABIBZADE, S., OMIDVAR, A., FARAHANI, M. R. M., AND MASHKOUR, M. Effect of Nano-ZnO on Decay Resistance and Artificial Weathering of Wood Polymer Composite. Journal of Nanomaterials and Molecular Nanotechnology, v. 3, n. 3, p. 2, 2014.
HAMMINGA, G. M.; MUL, G.; AND MOULIJN, J. A. Real-time in situ ATR-FTIR analysis of the liquid phase hydrogenation ofcbutyrolactone over $\mathrm{Cu}-\mathrm{ZnO}$ catalysts: a mechanistic study by varying lactone ring size. Chemical Engineering Science, v. 59, n. (22-23), 5479-5485, 2004.

HILL, C.A.S. The reduction in the fiber saturation point of wood due to chemical modification using anhydride reagents: $A$ reappraisal. Holzforschung, v. 62, n.4, p. 423-428, 2008.

HONG, R. Y.; LI, J. H.; CHEN, L. L.; LIU, D. Q.; LI, H. Z.; ZHENG, Y.; AND DING, J. Synthesis, surface modification and photocatalytic property of $\mathrm{ZnO}$ nanoparticles. Powder Technology, v. 189, n. 3, p. 426-432, 2009.

KAMAT, P. V.; HUEHN, R.; AND NICOLAESCU, R. A. Sense and Shoot approach for photocatalytic degradation of organic contaminants in water. The Journal of Physical Chemistry, v. 106, n. 4, 788-94, 2002.

KARIMI, A.; TAGHIYARI, H. R.; FATTAHI, A.; KARIMI, S.; EBRAHIMI, G. H.; AND TARMIAN, A. Effects of wollastonite nanofibers on biological durability of poplar wood (Populus nigra) against Trametes versicolor. BioResources, v. 8, n.3, 4I34-4I4I, 20I3.

KHANJANZADEH, H.; TABARSA, T.; SHAKERI, A.; AND OMIDVAR, A. Effect of organoclay platelets on the mechanical properties of wood plastic composite formulated with virgin and recycled polypropylene. Wood Material Science and Technology, v. 6, n.4, 207-2I2, 2011 .

KITANO, M.; AND SHIOJIRI, M. Benard convection $\mathrm{ZnO} /$ resin lacquer coating - a new approach to electrostatic dissipative coating. Powder Technology, v. 93, n.3, 267-73, 1997.

LI, D. Nanostructuring materials towards conventionally unachievable combination of desired properties. Journal of Nanomaterials and Molecular Nanotechnology, v. I, n.I, p. I-2, 2012

OZDEMIR, F.; AND TUTUS, A. The effects of some fire retardants on physical and mechanical properties of HDF panels covered with resin-impregnated paper. Lignocellulose, v. 2, n. 2, 329-337, 2013.

OZDEMIR, F; AND TUTUS, A. Effects of coating with calcite together with various fire retardants on the fire propertie of particleboard. BioResources, v. II, n. 3, p. 6407-64I5, 2016.

RANGAVAR, H.; TAGHIYARI, H. R.; OROMIEHIE, A.; GHOLIPOUR, T.; SAFARPOUR, A. Effects of nanoclay on physical and mechanical properties of wood-plastic composites. Wood Material Science \& Engineering, p.I-9, 2016.

RASHMI, R.; DEVI, K.; AND TARUN, K. Effect of Nano-ZnO on Thermal, 20I2, Mechanical, UV Sta Physical Properties of Wood Polymer Composites. M.Sc. thesis, Department of Chemical Sciences, Tezpur University, Napaam-784028, India, 3870-3880, 2012. 
RASHMI, R.; DEVI, K.; AND TARUN, K. Effect of nanofillers on flame retardancy, chemical resistance, antibacterial properties and biodegradation of wood/styrene acrylonitrile co-polymer composites. Wood Science \& Technology, v. 47, II35-II52, 2013.

SABER, R.; SHAKOORI, Z.; SARKAR, S.; TAVOOSIDANA, GH.; KHARRAZI, S. H.; AND GILL, P. Spectroscopic and microscopic analyses of rod-shaped gold nanoparticles interacting with single-stranded DNA oligonucleotides. IET Nanobiotechnology, v. 7, p. 42-49, 2013

SALARI, A.; TABARSA, T.; KHAZAEIAN, A.; AND SARAEIAN, A. Effect of nanoclay on some applied properties of oriented strand board (OSB) made from underutilized low quality paulownia (paulownia fortunei) wood. Journal of Wood Science, v. 58, n. 6, p. 5I3-524, 2012.

SCHMIDT, O. Indoor wood-decay basidiomycetes: damage, causal fungi, physiology, identification and characterization, prevention and control. Mycological Progress, v. 6, n. 4, p. 26 I-279, 2007.

SHU-RUI, M.A.; YI, S.; XIN, F; JUN, Y.; AND BO, L. Graft modification of $\mathrm{ZnO}$ nanoparticles with silane coupling agent $\mathrm{KH} 570$ in mixed solvent. Journal of Shanghai Jiatong University (Engl. Ed.), v. I2, n. 3, 278-282, 2008.

SOLTANI, M.; NAJAFI, A.; YOUSEFIAN, S.; NAJI, H.R.; AND SUHAIMI, B. E. Water repellent effect and dimension stability of beech wood impregnated with Nano-Zinc Oxide. BioResources, v. 8, n. 4, 6280-6287, 2013.

TAGHIYARI, H. R. Fire-Retarding Properties of Nano-Silver in Solid Woods. Springer: Wood Science \& Technology, v. 46, n. 5, p. $939-952,2012$

TAGHIYARI, H. R. Nanotechnology in Wood and WoodComposite Materials. Journal of Nanomaterials and Molecular Nanotechnology, v.3, n. I, 2014.
TAGHIYARI, H. R.; RANGAVAR, H.; AND NOURI, P. Fire-retarding properties of nanowollastonite in MDF. European Journal of Wood and Wood Products, v. 7I, n. 5 , p. 573-58I, 2013.

TANG, E.; CHANG, G.; AND MA, X. Preparation of nano ZnO/ PMMA composite particles via grafting of the copolymer onto the surface of zinc oxide nanoparticles. Powder Technology, v. I6I, p. 209-2।4, 2006.

TURTON, R., BERRY, D.A., GARDNER, TH., AND MILTZ, A. Evaluation of zinc oxide sorbents in a pilot-scale transport reactor: sulfidation kinetics and reactor modeling. Industrial Engineering and Engineering Chemical Research, v.43, n. 5, I235-1243, 2004.

WANG, Z.; YONGLAI, L.; LIU, J.; DANG, Z.; AND ZHANG, L. Preparation of Nano-Zinc Oxide/EPDM composites with both good thermal conductivity and mechanical properties. Journal of Applied Polymer Science, v. I I 9 , n. 2, p. II44-II55, 2010.

WANG, Z.; YANG, X.; SUN, B.; CHAI. Y.; LIU, J.; CAO, J. Effect of vacuum heat treatment on the chemical composition of larch wood. BioResources, v. I I, n. 3, p. 5743-5750, 2016.

WHITE, R.H.; AND DIETENBERGER, M. A. Wood Handbook, Chapter 17: Fire Safety; Forest Products Laboratory, Gen. Tech. Rep. FPL - GTR - I I3, Madison, WI: U.S. Department of Agriculture, Forest Service, And Forest Products Laboratory, 1999.

WU, J.; XIE, C. S.; BAI, Z.K.; ZHU, B. L.; HUANG K.J.;AND $\mathrm{WU}, \mathrm{R}$. Preparation of $\mathrm{ZnO}$-glass varistor from tetrapod $\mathrm{ZnO}$ nanopowders. Materials Science and Engineering, v. 95, n. 2, |57-6|, 2002.

WU, R.; AND XIE, C. S. Formation of tetrapod ZnO nanowhiskers and its optical properties. Materials Research Bulletin, v. 39, n. 4-5, 637-645, 2004. 
